\title{
Methane Production, Transport and Emission in Amazon Hydroelectric Plants
}

\author{
Ivan Bergier TAVARES DE LIMA \\ Instituto Nacional de Pesquisas Espaciais \\ Divisão de Sensoriamento Remoto \\ Caixa Postal, 515 \\ 12 227-010 - São José dos Campos, São Paulo \\ ivan@ltid.inpe.br \\ Evlyn Márcia Leão de Moraes NOVO \\ Instituto Nacional de Pesquisas Espaciais \\ Divisão de Sensoriamento Remoto \\ Caixa Postal, 515 \\ 12 227-010 - São José dos Campos, São Paulo \\ evlyn@1tid.inpe.br \\ Maria Victoria Ramos BALLESTER \\ Universidade de São Paulo \\ Centro de Energia Nuclear na Agricultura \\ Caixa Postal, 96 \\ 13416-000 - Piracicaba, São Paulo \\ vicky@cena.usp.br \\ Jean Pierre OMETTO \\ Universidade de São Paulo \\ Centro de Energia Nuclear na Agricultura \\ Caixa Postal, 96 \\ 13416-000 - Piracicaba, São Paulo \\ jpometto@cena.usp.br
}

A TM/Landsat5 time series was digitally processed to identify sample stations, according to the age of macrophyte stands. These areas were sampled to assess the respiratory process of the Tucurui reservoir, Pará State, Brazil. The results suggest that tributaries often occupied by floating macrophytes are significant methane sources to the atmosphere, where bubble fluxes are the main transport process. A methane concentration gradient in deep waters indicates horizontal fluxes from tributaries to the main channel. As a result, open water areas emit in diffusive fluxes a large amount of the methane produced in tributaries.

\section{INTRODUCTION}

There are evidences that methane concentration in the atmosphere has increased since the Industrial Revolution [1]. Sources and sinks of greenhouse gases (GHG), such as methane and carbon dioxide, must be evaluated in different latitudes [3]. Tropical rainforests are considered a carbon sink. Land-use changes induce a migration of carbon to the atmosphere [4].
In Amazonia, hydroelectric power plants induce GHG emission indirectly by logging and burning the surrounded forest, and directly by decomposition processes in the reservoir. Input of organic matter may be assigned to flooded forest, macrophyte stands, and the runoff. In order to check spatial differences of the methane emission in Tucurui reservoir (Pará State, Brazil) historical images were used to identify areas, where input of organic matter is distinct.

\section{METHODOLOGY}

\section{Digital Data Processing}

The reservoir was completely filled in 1984. Five TM Landsat 5 images, bands 3,4 and 5 , were used: June/86, August/88, July/90, June/92 and July/94. Of course the area covered by macrophytes is seasonally variable, however TM images in Amazonia are not available in wet season. In this case, the map classes are related to the dry season. Yet, dam operation results in non-drastic changes in the water depth, which may cause little variation in the extent of macrophyte stands. 
The June/1986 image was used as reference to correct geometrically the remaining data set. The same image was sliced to create a mask, covering only the reservoir to prevent mismatch classification. Smaller digital numbers were found inside the reservoir and that permitted creating the mask. Unsupervised classification was performed to the masked images, generating two classes for each one: macrophyte stands and open water. To produce a map including spatial and temporal variation in the macrophyte stands, boolean operations among classified images were carried out. Digital numbers were then regrouped into four classes, and the final map was used to identify areas i) never covered, ii) always covered, iii) temporarily covered, and iv) covered only in 1986 by floating macrophytes.

\section{Field Data Collecting}

The Sampling field work was carried out from 3 to 17 August in 1997. The physical and chemical parameters sampled were: depth, temperature, $\mathrm{pH}$, dissolved carbon dioxide, methane, and oxygen on the top and bottom of the water column. Methane fluxes between water-air interface were estimated using two approaches: the empirical model Thin Boundary Layer (TBL) and floating static chambers (FSC) $[2,3,6]$

\section{RESULTS AND DISCUSSION}

\section{Spatial-Temporal Variation of Macrophytes}

Fig. 1 presents the distribution of floating macrophytes in Tucuruí reservoir through the years 1986, 1988, 1990, 1992 and 1994. In the earliest year almost all reservoir banks were covered due to nutrients increase from submerged dead forest. Along the years, nutrients availability, as well as macrophyte area extent decreased. On the other hand, there are regions where occupation is constant (always covered class) during that period, even nowadays. These areas are located mainly in the reservoir tributaries. This fact is probably a consequence of i) nutrient maintenance from water column stratification and runoff, ii) the windless effect of dead trees or "paliteiro" on the stands, and iii) the lower hydrodynamic process.

\section{Water Physical and Chemical Spatial Variation}

Tributaries present distinct physical and chemical conditions. In these regions, water column (around $10 \mathrm{~m}$ ) is always stratified, resulting in dissolved oxygen depletion near the sediment surface. Such anaerobic condition is responsible for the methane bioproduction. Bacterial methanogenesis also results in production of carbon dioxide [5]. In relation to both carbon dioxide and methane, higher concentrations were found in deep waters of the tributaries (temporarily and always covered classes). Meanwhile, open waters (only in 1986 and never covered classes) showed lower methane and carbon dioxide concentrations. The water column of open water banks was well mixed, but stratified in the center of the main channel (around $60 \mathrm{~m}$ ). One can conclude that in the tributary sediments the major respiratory process is anaerobic, whereas at the open waters, aerobic decomposition predominates.

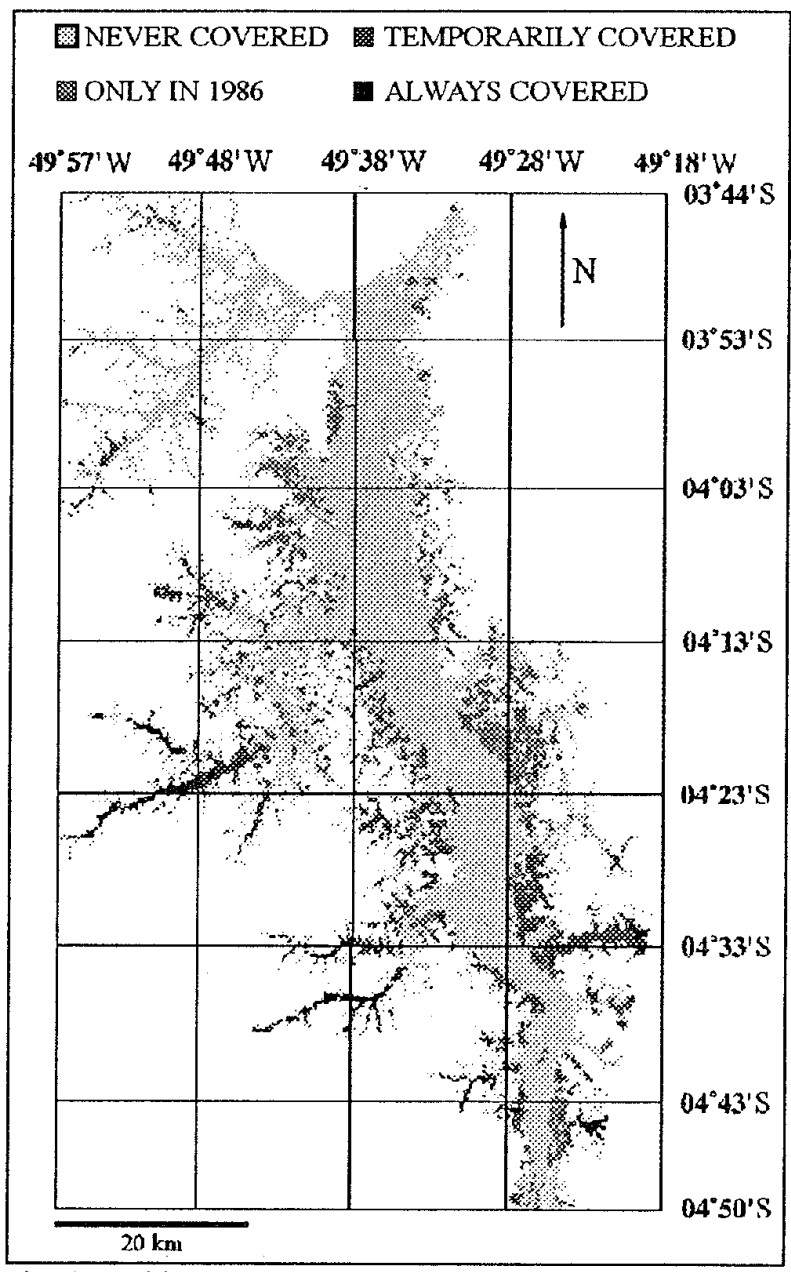

Fig. 1. Multitemporal analysis of floating macrophyte spread in Tucuruí dam.

\section{Methane Fluxes To The Atmosphere}

The descriptive statistics of methane fluxes are presented in Table 1. The non-parametric test Wilcoxon-Mann-Whitney showed no significant differences among classes for TBL fluxes $(p<0.05)$. However, the same test detected significant differences between always/temporarily and only in 1986 classes for FSC fluxes $(p<0.05)$. The FSC approach was one order of magnitude higher than TBL model (Table 1). These 
results may be due to the predominant ebullitive fluxes in tributaries (higher methanogenesis rates). Moreover, FSC is sensitive to both diffusive and ebullitive fluxes, while TBL estimates only the first one. Nevertheless, there are uncertainties related to which approach is more accurate for measuring methane emission [2].

Table 1. Estimated methane fluxes $\left(\mathrm{mgCH}_{4} \mathrm{~m}^{-2} \mathrm{~d}^{-1}\right)$ from Tucuruí dam. * standard deviation.

\begin{tabular}{|llcc|}
\hline Class & & TBL & FSC \\
\hline never covered & average & $4.32\left(4,49^{*}\right)$ & - \\
& median & 3.07 & - \\
& range & $0.15-13.19$ & - \\
& n & 8 & - \\
\hline only in 1986 & average & $6.03\left(3,59^{*}\right)$ & $\left.34.31(16,9)^{*}\right)$ \\
& median & 5.45 & 29.64 \\
& range & $1.39-11.01$ & $20.53-66.75$ \\
& n & 6 & 6 \\
\hline Temporarily covered & average & $7.39\left(4,34^{*}\right)$ & $94.25\left(79.90^{*}\right)$ \\
& median & 7.81 & 63.21 \\
& range & $0.85-13.14$ & $14.76-248.63$ \\
& n & 8 & 12 \\
\hline alwozys covered & average & $7.61\left(4.02^{*}\right)$ & $75.44(36.59 *)$ \\
& median & 8.10 & 79.93 \\
& range & $0.85-12.84$ & $18.69-141.92$ \\
& n & 9 & 14 \\
\hline
\end{tabular}

Hypolimnium Methane Migration

There are some evidences that part of the methane produced in tributaries is transported diffusely and hydrodinamically to the main channel in bottom waters. First, a methane gradient concentration was measured from tributary headwaters (always covered areas) to the main channel (never covered areas) (Fig. 2). The thermal stratification of the water column tributaries produces horizontal layers with different densities, which makes vertical methane diffusion difficult. However, diffusion normally takes place within the same layer. Since methane is produced in the sediment, a horizontal concentration gradient can be formed. Another migration evidence is the higher methane concentration measured in the left main channel edge, where most of the tributaries always covered by macrophytes are located (Fig. 3).

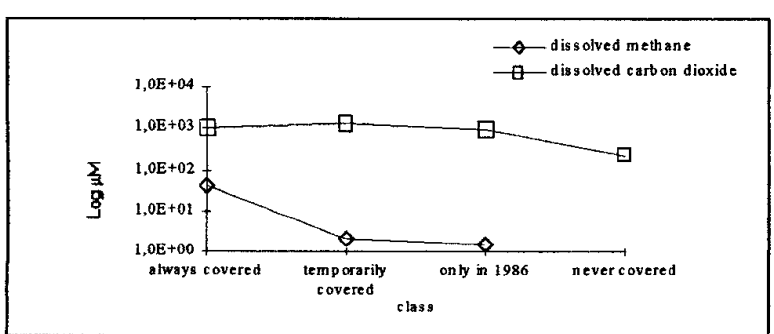

Fig. 2. Average methane and carbon dioxide gradient concentration in Pucuruí tributary $\left(49^{\circ} 48^{\prime} \mathrm{W} 4^{\circ} 21^{\prime} \mathrm{S}\right)$.

Thus, methane emission from open water may result partially from methane tributary discharges, which can occur if we consider that the labile organic matter from flooded forest had already been decomposed and the redox condition is aerobic in the main channel.
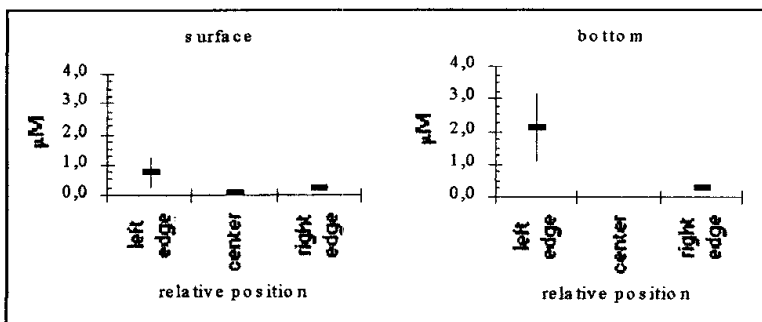

Fig. 3. Average (plus or minus 1' s.d.) methane concentration in the main channel.

\section{CONCLUSION}

Tropical hydroelectric power plants can be considered important methane sources to the atmosphere. At the early stage of flooding, the major source of organic matter is the flooded forest. Along the years, the macrophyte community has played an important role in the methanogenesis process, acting as a source of organic matter. Distinct physical and chemical conditions in different portions of the reservoir are related to the production, as well as to the methane emission.

\section{ACKNOWLEDGMENT}

This work was sponsored by FAPESP (96/4523-0). Invaluable logistic support was provided by Environmental Protection Center of ELETRONORTE-Tucuruí. Authors would like to thank Marco Aurélio Tavares de Carvalho for the text review.

\section{REFERENCES}

[1] B. Stauffer, G. Fischer, A. Neftel, and H. Oeschger. Increase of atmospheric methane recorder in antartic ice core. Science, 299:1386-1388, 1985.

[2] E. Duchemim, M. Lucotte, R. Canuel, and A. Chamberland. Production of greenhouse gases $\mathrm{CH}_{4}$ and $\mathrm{CO}_{2}$ by hydroelectric reservoirs of boreal region. Global Biogeochemical Cycles, 4:529-540, 1995.

[3] K.B. Bartlett, and R.C. Harris. Review and assessment of methane emissions from wetlands. Chemosphere, 26:261$320,1993$.

[4] P.M. Fearnside. Greenhouse gases from deforestation in Brazilian Amazonia: net commited emissions. Climatic Change, 35:321-360, 1997

[5] R.J. Cicerone, and R.S. Oremland. Biogeochemical aspects of atmospheric methane. Global Biogeochemical Cycles, 2:299-327, 1988.

[6] W.S Broecker, and T.H. Peng. Gas exchange rates between air and sea. Tellus, 26:21-35, 1974. 